ZOOLOGIA 31 (3): 209-214, June, 2014

http://dx.doi.org/10.1590/S1984-46702014000300001

\title{
Behavior and foraging technique of the Ingram's squirrel Guerlinguetus ingrami (Sciuridae: Rodentia) in an Araucaria moist forest fragment
}

\author{
Calebe Pereira Mendes ${ }^{1,3}$ \& José Flávio Cândido-Jr²
}

\begin{abstract}
1 Laboratório de Biologia da Conservação, Instituto de Biociências, Universidade Estadual Paulista "Júlio de Mesquita Filho". Avenida 24 A 1515, 13506-900 Rio Claro, São Paulo, Brazil.

2 Laboratório de Zoologia dos Vertebrados e Biologia da Conservação, Centro de Ciências Biológicas e Saúde, Universidade Estadual do Oeste do Paraná. Rua Universitária 1619, 85819-110 Cascavel, PR, Brazil.

${ }^{3}$ Corresponding author. E-mail: calebepm3@hotmail.com
\end{abstract}

\begin{abstract}
This work describes the foraging techniques, body positions and behavior of free-ranging Ingram's squirrel Guerlinguetus ingrami Thomas, 1901 in a region of the Araucaria moist forest, in the Atlantic Forest of southern Brazil. The animals were observed using the "all occurrence sampling" method with the aid of binoculars and a digital camcorder. All behaviors were described in diagrams and an ethogram. We recorded five basic body positions, 24 behaviors, two food choices, and three feeding strategies utilized to open fruits of Syagrus romanzoffiana (Cham.), the main food source of Ingram's squirrels. We also observed a variance in the animals' stance, which is possibly influenced by predation risk, and discuss the causes of some behaviors.
\end{abstract}

KEY WORDS. Atlantic forest; body position; ethogram; Syagrus romanzoffiana.

Ingram's squirrel, Guerlinguetus ingrami Thomas, 1901, sometimes considered a subspecies of G. aestuans or placed in Sciurus (Allen 1915, Moojen 1942) and commonly known as Atlantic Forest squirrel or "serelepe", is one of 11 species of Sciuridae documented in Brazil (Ress et al. 2011). The species occurs from southeastern Bahia to northern Rio Grande do Sul and is arboreal and diurnal, inhabiting primary or secondary growth areas of the Atlantic Forest and "Cerrado" (Bonvicino et al. 2008). Despite its wide distribution throughout Brazil, 'the elusive habits of this squirrel make it difficult to unravel various aspects of its biology. The little available information about the diet of G. ingrami indicates that it is composed mainly of fruits and seeds, but it may also include flowers, tree bark, mushrooms, lichens, moss, bird eggs, leaves and insects (Bordignon et al. 1996, Miranda 2005, Ribeiro et al. 2009, 2010).

The Atlantic Forest squirrel is often associated with the queen palm, Syagrus romanzoffiana (Cham.) Glassman. The abundance of this palm influences the location of squirrel nests (Alvarenga \& Talamoni 2005). The S. romanzoffiana is also an important resource for $G$. ingrami even in areas where the palm is not abundant, because the palm's fruits may comprise a large portion of the squirrel's diet, in particular seasons and regions (Galetti et al. 1992, Paschoal \& Galetti 1995). In all tropical areas where they occur, sciurids are both seed predators and seed dispersers (STONER et al. 2007). However, since the ecological interactions of a particular species is dependent on its behavioral patterns (McConkey \& DraKe 2006, OrRock \& Danielson 2005), and the behavior and ecology of G. ingrami in the wild are still largely unknown (Alvarenga \& Talamoni 2005, Miranda 2005), this study aimed to record the behavioral and foraging patterns of $G$. ingrami in an Araucaria moist forest fragment in southern Brazil.

\section{MATERIAL AND METHODS}

The study was conducted between April 2010 and September 2011 in a forest fragment on the São Domingos farm $\left(25^{\circ} 01^{\prime} 37^{\prime \prime} \mathrm{S}, 5^{\circ} 20^{\prime} 57^{\prime \prime} \mathrm{W}\right)$ and its surroundings in Cascavel, Paraná, Brazil. The fragment is approximately 1,300 ha in size and is connected to other smaller fragments though riparian forests. The region is primarily composed of Araucaria moist forest at various levels of degradation, but with plots of Pinus spp. and Eucaliptus spp. The average annual precipitation in the region is $1,800 \mathrm{~mm}$ and the average annual temperature is $19^{\circ} \mathrm{C}$. The climate is classified as Cfa according to the Köpper climate classification (IAPAR 2000).

Observations were made during eighteen months, with a mean of 2.5 ( $\mathrm{sd}=1.09)$ surveys per month - except for July 2011 when there was no sampling. The surveys were made between 08:00 a.m. and 01:30 p.m. and occasionally (five surveys) between 01:00 p.m. and 07:00 p.m., the periods of higher levels of activity for this species (Bordignon \& Monteiro-Filho 2000), totaling 160 hours of field effort. The surveys were conducted by walking along two trails (1.5 and $2 \mathrm{~km}$ in length) and two rural roads (1.5 and $0.5 \mathrm{~km})$, searching for animals with the help of binoculars ( $8 \times 40 \mathrm{~mm}$ ). The sightings were

2014 Sociedade Brasileira de Zoologia | www.sbzoologia.org.br | www.scielo.br/zool All content of the journal, except where identified, is licensed under a Creative Commons attribution-type BY-NC. 
filmed with a Sony DCR-SR47 camcorder on a tripod, in order to later analyze, describe, and score the behaviors. The list of behaviors for the species was elaborated using the "all occurrence sampling" method (Del-Claro 2004), and the data were organized in an ethogram. Seasonal analyses were not carried out because this was not the objective of the study. No animals were captured or marked in the study, but considering the small home range of the specie (Bordignon \& MonteiroFiLho 2000), it is possible that we observed at least six different animals.

To better understand the foraging techniques of $G$. ingrami feeding on fruits of $S$. romanzoffiana, fruits with predation marks were collected, washed and measured, and the predation marks were compared with one another.

\section{RESULTS}

The field effort resulted in 16 sightings, five hours and a half of observations and three hours and forty minutes of footage. Five basic body positions were recorded (Table I, Figs 1-4) and 24 behaviors were observed (Table II, Figs 5-7), which were divided into the following categories: maintenance, locomotion, foraging, agonistic, and territorial.
Throughout the study, the squirrels were observed eating two food items: fruits from the palm S. romanzoffiana and an unidentified moss. The consumption of bryophytes was observed only for one juvenile squirrel in December, while the fruits of $S$. romanzoffiana were consumed throughout the year. Although the squirrels mainly eat the endosperm of ripe and unripe fruits, they were also seen eating the epicarp and mesocarp of ripe fruits in December.

Three strategies for opening $S$. romanzoffiana fruits were identified in the visual records. The principal method, observed $50 \%(\mathrm{n}=28)$ of the time, consisted of cutting a triangular opening from the germination pore on the endocarp (Fig. 8). The second most utilized strategy, recorded $16.7 \%$ of the time, consisted of cutting along the circumference of the fruit, dividing it into two pieces (Fig. 9). In 33.3\% of the visual records, it was not possible to identify the strategy utilized by the animal. However from the eaten fruits, it was possible to distinguish a strategy that consisted of making various incisions side by side, which resulted in a single opening.

We observed that the process of opening the endocarp with the triangular opening strategy in $95.5 \%(n=534)$ of the cases was performed on the opposite side of the inner gibbosity of the endocarp, where the endocarp is thinner and allows
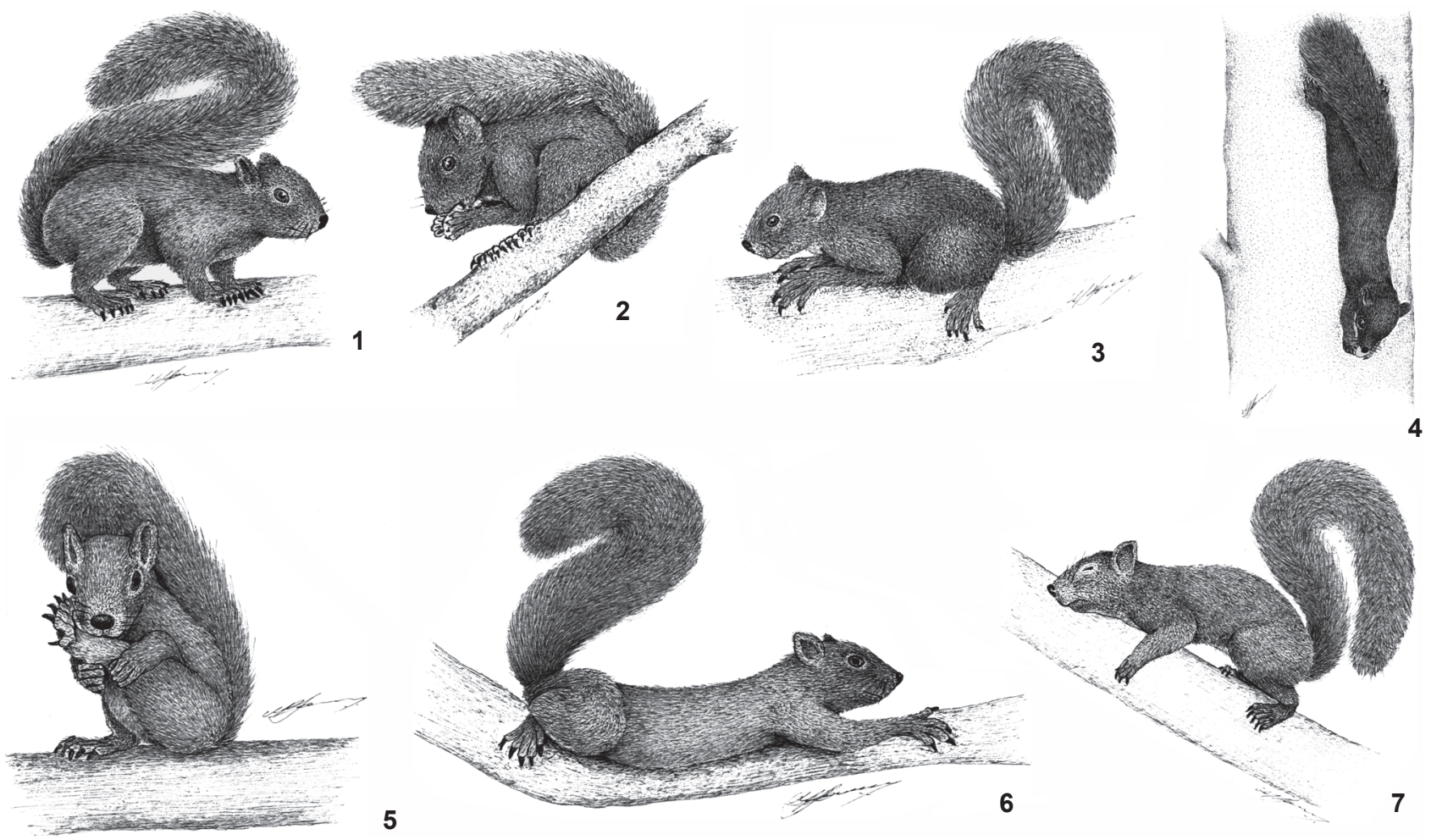

Figures 1-7. (1-4) Basic body positions: (1) standing; (2) sitting, with the tail above the head; (3) lying down; (4) suspended position; (5) cratch posterior limb behavior; (6) stretch behavior; (7) cheek rubbing behavior. 
Table I. Description of the basic body positions used by Guerlinguetus ingrami.

\begin{tabular}{|c|c|}
\hline Basic body positions & Description \\
\hline Standing & $\begin{array}{l}\text { The squirrel uses its four limbs to support itself and the body is parallel to the substrate. The tail assumes an } S \text { shape and sits over } \\
\text { the animal's dorsal region (Fig. 1). }\end{array}$ \\
\hline Sitting & $\begin{array}{l}\text { The squirrel bends its posterior limbs to support itself on the substrate. The animal's body remains arched, and the animal's } \\
\text { anteroposterior axis forms an angle from } 0^{\circ} \text { to } 30^{\circ} \text { relative to the ground. The anterior limbs may be touching the ground or remain } \\
\text { free in order to execute tasks such as food manipulation or maintenance behavior (Fig. 2). The tail remains either over the animal's } \\
\text { dorsal region in an S shape or above the head pointing forward. }\end{array}$ \\
\hline Lying down & $\begin{array}{l}\text { The squirrel supports its ventral region and limbs on the substrate. The anterior limbs are positioned forward and the head rests upon } \\
\text { them, while the posterior limbs are positioned close to } 90^{\circ} \text { from the anteroposterior axis of the animal. The tail assumes an } \mathrm{S} \text { shape } \\
\text { over the rodent's dorsal region (Fig. } 3 \text { ). }\end{array}$ \\
\hline Alert position & $\begin{array}{l}\text { The squirrel assumes the standing position, but the tail is bristled and erect, forming approximately a } 90^{\circ} \text { angle with the } \\
\text { anteroposterior axis of the animal. While in this stance, the animals often position themselves in locations with good visibility, } \\
\text { frequently flagging their tail and vocalizing. This behavior was also reported for an adult individual when observers approached its } \\
\text { nest in which a juvenile was sitting. }\end{array}$ \\
\hline Suspended position & $\begin{array}{l}\text { The squirrel uses only the posterior limbs to support itself on a vertical substrate, with the head turned downward. The ventral region } \\
\text { touches the substrate, and the anterior limbs remain free to execute tasks such as food manipulation. The tail remains turned upward } \\
\text { and is touching the substrate, continuous with the animal's anteroposterior axis (Fig. } 4 \text { ). }\end{array}$ \\
\hline
\end{tabular}

access to the fruit's endosperm (Fig. 10). This process lasts an average of 70 seconds $(n=18, s d \pm 20)$, followed by the animal taking an average of 83 seconds $(n=19, s d \pm 31)$ to eat the fruit's endosperm. The area of the triangular opening is not correlated with fruit size (Pearson correlation test, $\mathrm{r}=0.02, \mathrm{df}$ $=512, \mathrm{p}=0.61)$. We also observed that all of the individuals who used the triangular opening strategy were adults, and only one adult individual did not use this technique.
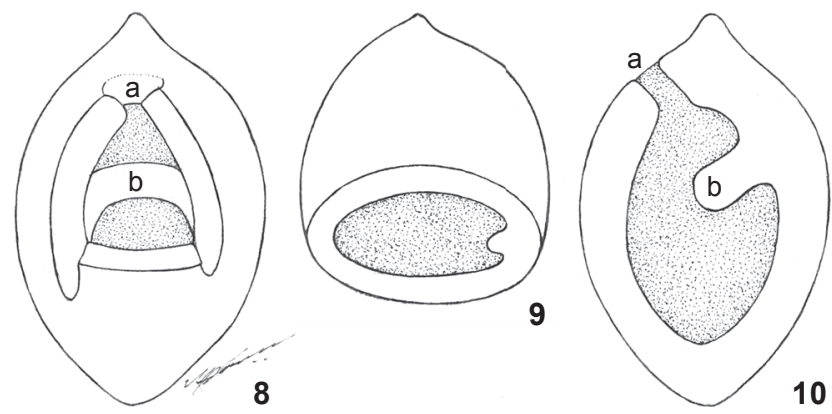

Figures 8-10. (8) Triangular opening strategy; (9) Circular opening strategy; (10) Internal anatomy of the fruit Syagrus romanzoffiana showing the germination pore (a) and the inner gibbosity (b).

\section{DISCUSSION}

\section{Basic body positions}

In the current study, we observed that the "sitting" body position (Fig. 2) differed from the reports in the literature. Bordignon \& MONTEIRO-FilHo (1997) found that when in the "sitting" position the anteroposterior axis of the animal stayed close to $45^{\circ}$ relative to the substrate, but in our study an angle of approximately $20^{\circ}$ was observed, and it rarely reached $30^{\circ}$. Given that the authors studied captive animals (Bordignon \& MonTEIroFilHo 1997), the difference in angle may occur because of the predation risk that wild animals face. In this case, maintaining the body closer to the substrate may reduce the chance of being detected by potential predators. The "sitting" body position is also known in the literature as "Position of lying" often used when the animal feels threatened (Ribeiro et al. 2009).

In addition to assuming a position closer to the substrate, the behavior of maintaining the tail pointing forward above the dorsal region and head instead of the $S$ shape while sitting, may also be a strategy to prevent the predator from delimiting the animal's body position, thus minimizing its detection. The behavior of maintaining the tail pointing forward instead of in the $S$ shape while in the sitting position appears to have no connection with the thermoregulatory behavior exhibited by other sciurids. For example, the Cape ground squirrel Xerus inauris (Zimmermann, 1780) (FICK et al. 2009) appears to use the tail to make shade, whereas in the current study the animals also exhibit this behavior in the shade. This supports the hypothesis that the tail may be used as camouflage. The use of the elongated, bristly tail in a disruptive way, the cryptic coloration, the small size, and the "hide" and "vigilant" behaviors turns the squirrel into a very discrete species in its natural environment, and this significantly reduces the risk of predation.

The "alert position" reported in our study differs from the "Attack position" reported by Ribeiro et al. (2009) in that only the tail that remains aligned with the animal's anteroposterior axis, but both positions are used in agonistic situations. The "standing" (Fig. 1), "lying down" (Fig. 3) and "suspended" (Fig. 4) positions were also documented by other authors (Bordignon et al. 1996, Bordignon \& Monteiro-Filho 1997, Ribeiro et al. 2009).

\section{Feeding behavior and diet}

The variety of food sources reported in this study was quite different from those registered in the literature. While in 
Table II. Ethogram containing the descriptions of the behaviors observed for the squirrel Guerlinguetus ingrami.

\begin{tabular}{|c|c|c|}
\hline Behaviors & $\%$ of time used & Description \\
\hline Maintenance Behaviors & 2 & \\
\hline Scratch head & 0.27 & $\begin{array}{l}\text { While sitting with the four limbs on the ground, the squirrel moves one posterior limb to the head and turns the } \\
\text { head to the side, approaching the area to be scratched by the hind limb. The animal rubs the limb against the head. }\end{array}$ \\
\hline Scratch back & 0.49 & $\begin{array}{l}\text { While sitting with the four limbs on the ground, the rodent moves the head laterally in the direction of the } \\
\text { back and bites the dorsal region and the base of the tail. }\end{array}$ \\
\hline Scratch armpit & 0.04 & $\begin{array}{l}\text { While sitting with the four limbs on the ground, the animal raises one anterior limb exposing the armpit } \\
\text { which is then rubbed by a posterior limb from the same side. }\end{array}$ \\
\hline Scratch anterior limb & 0.06 & $\begin{array}{l}\text { In the sitting position, the squirrel brings an anterior limb to its mouth and bites, while the opposite anterior } \\
\text { limb helps to hold the limb being bitten. }\end{array}$ \\
\hline Scratch posterior limb & 0.05 & $\begin{array}{l}\text { While sitting, the squirrel uses both anterior limbs to hold and bring a posterior limb to the mouth, then the } \\
\text { animal bites the posterior limb (Fig. 5). }\end{array}$ \\
\hline Lick hands & 0.08 & While sitting, the rodent brings both posterior limbs to its mouth and licks them. \\
\hline Stretch & 0.04 & $\begin{array}{l}\text { The animal supports its posterior limbs on the ground and stretches the anterior limbs forward, curving the } \\
\text { spine back. The tail remains turned upward forming an S shape (Fig. 6). }\end{array}$ \\
\hline Scare away mosquitoes & 0.09 & $\begin{array}{l}\text { When in the sitting position, the squirrel uses the long, furry tail to swat mosquitoes from the head region. } \\
\text { When in the standing position, the squirrel moves the head quickly to scare away mosquitoes close to its } \\
\text { face. When the head twitches do not suffice, the rodent brings one anterior limb to its head and rubs it } \\
\text { against its cheek, thus swatting the insects. }\end{array}$ \\
\hline Collect plant fiber & 0.87 & $\begin{array}{l}\text { The animal collects plant fiber by removing tree bark. After collecting, the squirrel holds the plant fiber in its } \\
\text { mouth, while it kneads the fibers with its anterior limbs until it forms a matted, cohesive mass. The animal } \\
\text { then transports the fiber mass to the nest. }\end{array}$ \\
\hline Locomotion Behaviors & 14 & \\
\hline Horizontal displacement & & $\begin{array}{l}\text { While standing, the squirrel positions the posterior limbs near the anterior limbs and jumps in the direction of } \\
\text { the movement. During the jump, the animal extends the front limbs forward, using them to cushion the } \\
\text { landing. Upon contact with the substrate, the squirrel again draws the posterior limbs close to the anterior } \\
\text { limbs, allowing it to jump again. During the movement, the tail generally remains extended in the opposite } \\
\text { direction of the movement. The animal was never observed walking at a slow pace without jumping. }\end{array}$ \\
\hline Vertical displacement & & $\begin{array}{l}\text { While standing, the squirrel supports itself with the anterior limbs while the posterior limbs are bent, drawing } \\
\text { them closer to the anterior limbs. The animal then uses the posterior limbs to support itself on the substrate, } \\
\text { and launches itself in the direction of the movement, positioning the anterior limbs forward. After the } \\
\text { launch, the rodent returns to supporting itself with the anterior limbs while repositioning the posterior limbs. } \\
\text { The head remains turned toward the direction of the movement, whether ascending, descending or moving } \\
\text { horizontally, while the tail typically remains extended in the opposite direction of the movement. }\end{array}$ \\
\hline Lateral displacement & & $\begin{array}{l}\text { While on a vertical substrate, after standing and with the head turned upward or downward, the squirrel uses the hind } \\
\text { limbs to support itself on the substrate, while it moves the anterior limbs to the side in the direction of the movement. } \\
\text { Subsequently, the rodent uses the anterior limbs to support itself on the substrate, while the posterior limbs move in } \\
\text { the same direction, aligning with the anterior limbs. The movement occurs in a perpendicular motion to the } \\
\text { anteroposterior axis of the animal, and the tail typically remains extended in the direction opposite of the head. }\end{array}$ \\
\hline Jump & & $\begin{array}{l}\text { While standing, the squirrel brings its anterior and posterior limbs closer together, bending its back and } \\
\text { posterior limbs. The animal then jumps and extends the anterior limbs forward, using them to absorb the } \\
\text { landing. The tail typically remains extended in the opposite direction of the movement. }\end{array}$ \\
\hline Transport & 2.15 & $\begin{array}{l}\text { The squirrel transports items of food and materials for the nest in its mouth, holding them with its teeth, thus } \\
\text { leaving the limbs to move freely. }\end{array}$ \\
\hline Foraging Behaviors & 78.3 & \\
\hline Peel fruit & 6.24 & $\begin{array}{l}\text { This behavior was reported based on the consumption of the fruits of } S \text {. romanzoffiana. From the sitting or } \\
\text { hanging positions, the animal uses the anterior limbs to hold and manipulate the fruit. With the incisors, the } \\
\text { rodent takes off the fruit's epicarp and the mesocarp, exposing the endocarp. The process lasts an average of } \\
14 \text { seconds for unripe fruits, but may last longer than one minute for ripe fruits. }\end{array}$ \\
\hline Gnaw & 44.30 & $\begin{array}{l}\text { While sitting or hanging, the squirrel uses the anterior limbs to hold and manipulate the peeled fruit. Using } \\
\text { the incisors, the animal gnaws and perforates the endocarp, exposing the endosperm. }\end{array}$ \\
\hline Eat endosperm & 27.30 & $\begin{array}{l}\text { While sitting or hanging, the squirrel uses the anterior limbs to hold and manipulate the opened endocarp. } \\
\text { With its teeth, the animal removes the endosperm from inside the perforated endocarp and consumes it. }\end{array}$ \\
\hline Eat moss & 0.45 & While standing, the squirrel uses the teeth to scrape moss from the substrate, consuming it in the same location. \\
\hline Agonistic Behaviors & 5.5 & \\
\hline Alarm call & ** & The squirrel emits a high-pitched, short, shrill sound, similar to a chirp. \\
\hline Tail flag & ** & The animal twitches the tail erratically, making it easily visible. \\
\hline Vigilant & 5.52 & The animal remains still for long periods of time, observing a possible threat. \\
\hline Hide & ** & $\begin{array}{l}\text { The rodent hides behind a trunk, branch or other object. If the possible threat circles the object, the squirrel } \\
\text { also circles the object, always staying on the opposite side of the threat. }\end{array}$ \\
\hline Territorial Behaviors & 0.1 & \\
\hline Cheek rubbing & 0.12 & $\begin{array}{l}\text { While sitting or standing, the squirrel bends the front limbs and rubs the sides of its cheeks against the } \\
\text { substrate (Fig. 7). }\end{array}$ \\
\hline Urinate & ** & While standing, the squirrel remains still while urinating on the substrate. \\
\hline
\end{tabular}

ZOOLOGIA 31 (3): 209-214, June, 2014 
our study only two types of food were consumed, Miranda (2005) reported 10, PASCHOAL \& GaletTi (1995) 14, and Bordignon $\&$ Monteiro-Filho (1999) 13 different types of food sources. It is possible that detecting this difference could be an artifact caused by the relatively small sample size of the present study. Both Paschoal \& Galetti (1995) and Bordignon \& Monteiro-Filho (1999) did more than 1,000 hours of field effort, however, Miranda (2005) registered only 25 sightings with less than four hours of naturalistic observations and also registered more food types than the present work.

Another possibility is that the weighted consumption of S. romanzoffiana may result from the abundance of this fruit, and its presence in every month of the year at the study site. In addition, it has been well-documented in the literature that the queen palm is an important part of the diet of G. ingrami. Paschoal \& GaletTI (1995) found that during August, the queen palm accounted for $90 \%$ of the reported food sources of $G$. ingrami. Intense consumption of $S$. romanzoffiana was also reported by various other authors (Alvarenga \& TAlamoni 2006, Bordignon et al. 1996, Bordignon \& Monteiro-Filho 1999, Miranda 2005). Other possible food sources are present at the study site, but were apparently not consumed by the squirrels. For instance, the pine Araucaria angustifolia, a species that is consumed by $G$. ingrami according to other studies (BoRdignon \& MonTeIro-Filho 1999, Miranda 2005), was not found to be eaten by the animals.

The fact that only adult individuals used the triangular opening strategy for fruits indicates that this behavior is learned (Ades \& Busch 2000). How the animal identifies the side opposite of the fruit's inner gibbosity before opening it is still not well understood, since externally the endocarps have tri-radial symmetry with three very similar holes.

Given that only one of the three holes is the functional germination pore, located opposite to the inner gibbosity, and the other two are merely cavities that do not extend to the center, BoRdignon et al. (1996) proposed that the animal tries to penetrate these holes with the incisors to identify which of them is the germination pore. MAIA et al. (1987) suggested that the animals may identify the germination pore by the small asymmetries in the hole. However, in the present study, we observed that the animals rarely clean out the fruit completely and do not expose all of the pores to allow for a comparison of their locations.

\section{Territorial and agonistic behavior}

All of the vocalizations of $G$. ingrami reported in this study were made in agonistic situations, often coupled with "vigilant", "tail flag", and "alert position" behaviors. The vocalizations may serve to warn the predator that it has been detected, thus discouraging an attack; to alert other individuals of the presence of a potential threat; and/or to distract the predator's attention while other animals escape or remain still among branches (SolóRzano-FilHo 2006). However, with one exception, the present study detected this behavior only in animals that appeared to be alone.
The "cheek-rubbing" behavior is also called "face-wiping" or "territorial marking" in the literature (BoRDIGNON et al. 1996, Halloran \& Bekoff 1995). According to Ribeiro et al. (2009), during this behavior, the squirrel deposits secretions from the gland in the oral-labial region on a given substrate. Despite this, the function of this behavior is controversial, as various authors classify it as a form of marking territory, while others believe it is part of grooming behavior. In a study with Abert's squirrels Sciurus aberti Woodhouse, 1853, HALLORAN \& BEKOFF (1995) showed that the facial marking behavior is more related to grooming than to territorial marking, but they did not reject a territorial function for the behavior. The authors claim that the facial marking behavior of $S$. aberti may have a secondary territorial function, and that the functions of this behavior may vary among species. The function of the facial marking behavior of G. ingrami has not been evaluated, and during our study we observed this behavior both during foraging and agonistic situations, which supports the idea that the behavior has more than one function, as was also observed for $S$. aberti.

Our study recorded a broad spectrum of behaviors performed by $G$. ingrami in the wild. Some are similar to behaviors already documented in the literature, and others present differences with important implications. For instance, the basic body positions potentially vary in response to predation risk; therefore studying the proximate causes of these variations would be quite useful to better understand the evolution of the species' behavior. It is quite probable that the facial marking behavior of this species has two functions, territorial and maintenance, but more specific research is necessary to evaluate these hypotheses.

\section{ACKNOWLEDGMENTS}

We thank Parque Tecnológico Itaipu for the financial support, the Laboratório de Zoologia dos Vertebrados e Biologia da Conservação of the Universidade Estadual do Oeste do Paraná - Campus Cascavel, and to Cássio Stringari, owner of the study area.

\section{LITERATURE CITED}

Ades, C. \& S.E. Busch. 2000. A aprendizagem do descascamento de sementes pelo camundongo Calomys callosus (Rodentia, Cricetidae). Revista Brasileira de Zoociências 2 (1): 31-44.

Allen, J.A. 1915. Review of the South American Sciuridae. Bulletin American Museum of Natural History 34: 147-309.

Alvarenga, C.A. \& S.A. Talamoni. 2005. Nests of the Brazilian squirrel Sciurus ingrami Thomas (Rodentia, Sciuridae). Revista Brasileira de Zoologia 22 (3): 816-818. doi: 10.1590/ S0101-81752005000300048.

Alvarenga, C.A. \& S.A. Talamoni. 2006. Foraging behaviour of the Brazilian squirrel Sciurus aestuans (Rodentia, Sciuridae). Acta Theriologica 51 (1): 69-74. doi: 10.1007/BF03192657. 
Bonvicino, C.R.; J.A. Oliveira \& P.S D'Andrea. 2008. Guia dos Roedores do Brasil, com chaves para gêneros baseadas em caracteres externos. Rio de Janeiro, Centro Pan-Americano de Febre Aftosa - OPAS/OMS. ISSN: 0101-6970.

Bordignon, M.; T.C.C. Margarido \& R.R. Lange. 1996. Formas de abertura dos frutos de Syagrus romanzoffiana (Chamisso) Glassman efetuadas por Sciurus ingrami Thomas (Rodentia, Sciuridae). Revista Brasileira de Zoologia 13 (4): 821-828. doi: S0101-81751996000400002.

Bordignon, M. \& E.L.A. Monteiro-Filho. 1997. Comportamentos e atividade diária de Sciurus ingrami (Thomas) em cativeiro (Rodentia, Sciuridae). Revista Brasileira de Zoologia 14 (3): 707-722. doi: 10.1590/S0101-81751997000300019.

Bordignon, M. \& E.L.A. Monteiro-Filho. 1999. Seasonal food resources of the squirrel Sciurus ingrami in a secondary araucaria forest in southern Brazil. Studies on Neotropical Fauna and Environment 34: 137-140. doi: 10.1076/snfe.34.3.137.8910.

Bordignon, M. \& E.L.A. Monteiro-Filho. 2000. Behaviour and daily activity of the squirrel Sciurus ingrami in a secondary araucaria forest in southern Brazil. Canadian Journal of Zoology 78: 1732-1739. doi: 10.1139/z00-104.

Del-Claro, K. 2004. Comportamento animal - Uma introdução à ecologia comportamental. Jundiaí, Conceito. ISBN: 85-89874-02-8.

Fick, L.G.; T.A. Kucio; A. Fuller; A. Matthee \& D. Mitchell. 2009. The relative roles of the parasol-like tail and burrow shuttling in thermoregulation of free-ranging Cape ground squirrels, Xerus inauris. Comparative Biochemistry and Physiology, Part A 152 (3): 334-340. doi: 10.1016/ j.cbpa.2008.11.004.

Galetti, M.; M. Paschoal \& F. Pedroni. 1992. Predation on palm nuts (Syagrus romanzoffiana) by squirrels (Sciurus ingrami) in south-east Brazil. Journal of Tropical Ecology 8 (1): 121123. doi: $10.1017 /$ S0266467400006210.

Halloran, M.E. \& M. BeKoff. 1995. Cheek rubbing as grooming by Abert squirrels. Animal Behaviour 50: 987-993. doi: 10.1016/0003-3472(95)80099-9.

IAPAR. 2000. Cartas climáticas do estado do Paraná. Londrina, Instituto Agronômico do Paraná.

Maia, A.A.; F.P. Serran; H.Q.B. Fernandes; R.R. Oliveira; R.F. Oliveira \& T.M.P.A. Penna. 1987. Inferências faunísticas por vestígios vegetais. III: Inter-relações do caxinguelê (Sciurus aestuans ingrami, Thomas 1901) com a palmeira baba-deboi (Syagrus romanzoffiana (Chamisso) Glassman). Atas da
Sociedade Botânica do Brasil, Secção Rio de janeiro 3 (11): 89-96.

McConkey, K.R. \& D.R. Drake. 2006. Flying foxes cease to function as seed dispersers long before they become rare. Ecology 87 (2): 271-276. doi: 10.1890/05-0386.

Miranda, J.M.D. 2005. Dieta de Sciurus ingrami Thomas (Rodentia, Sciuridae) em um remanescente de floresta com Araucária, Paraná, Brasil. Revista Brasileira de Zoologia 22 (4): 1141-1145. doi: 10.1590/S0101-81752005000400047.

Moojen, J. 1942. Sobre os "ciurídeos" das coleções do Museu Nacional, do Departamento de Zoologia de S. Paulo e do Museu Paraense Emílio Goeldi. Boletim do Museu Nacional, Zoologia 1: 55.

OrRock, J.L.; Danielson B.J. 2005. Patch shape, connectivity, and foraging by oldfield mice (Peromyscus polionotus). Journal of Mammalogy 86: 569-575. doi: 10.1644/1545-1542(2005) 86[569:PSCAFB]2.0.CO;2.

Paschoal, M. \& M. Galetti. 1995. Seasonal food use by the neotropical squirrel Sciurus ingrami in southeastern Brazil. Biotropica 27 (2): 268-273. doi: 10.2307/2389006.

Reis, N.R.; A.L. Peracchi; W.A. Pedro \& I.P. Lima. 2011. Mamíferos do Brasil. Londrina, Universidade Estadual de Londrina, $2^{\text {nd }}$ ed.

Ribeiro, L.F.; L.O.M. Conde; L.C. Guzzo \& P.R Papalambropoulos. 2009. Behavioral patterns of Guerlinguetus ingrami (Thomas, 1901) from three natural populations in Atlantic forest fragments in Espirito Santo state, Southeastern Brazil. Natureza on line 7 (2): 92-96. Available online at: http:// www.naturezaonline.com.br/natureza/conteudo/pdf/ 06_RibeiroLFetal_9296.pdf [Accessed: 01/IX/2013].

Ribeiro, L.F.; L.O.M. Conde \& M. Tabarelli. 2010. Predação e remoção de sementes de cinco espécies de palmeiras por Guerlinguetus ingrami (Thomas, 1901) em um fragmento urbano de floresta Atlântica montana. Árvore 34 (4): 637649. doi: 10.1590/S0100-67622010000400008.

SolórzANo-FilHo, J.A. 2006. Mobbing of Leopardus wiedii while hunting by a group of Sciurus ingrami in an Araucaria forest of Southeast Brazil. Mammalia 70: 156-157. doi: 10.1515/ MAMM.2006.031.

Stoner K.E.; P. Riba-Hernández; K. Vulinec; J.E. Lambert. 2007. The Role of Mammals in Creating and Modifying Seedshadows in Tropical Forests and Some Possible Consequences of Their Elimination. Biotropica 39: 316-327. doi: 10.1111/j.17447429.2007.00292.x.

Submitted: 16.X.2013; Accepted: 04.V.2013.

Editorial responsibility: Diego Astúa de Moraes

ZOOLOGIA 31 (3): 209-214, June, 2014 